\title{
A New Variety of Pullularia fermentans Wynne et Gott
}

\author{
by Minoru Yoneyama*
}

\author{
米山穣*: Pullularia fermentans Wynne et Gott の新変種
}

Received January 6, 1959

An interesting fungus degrading rutin in a peculiar way ${ }^{1)}$ was encountered and isolated by Dr. S. Hattori and his co-worker in their laboratory of Tokyo and was sent to the author for identification. At first the newly isolated fungus appeared to belong to the group of "Yeast" because of 1) the abundance of free cell formation of the fungus ${ }^{2}$ and 2) its lack of dark pigmentation. Further investigation, however, seemed to justify its inclusion in the genus Pullularia, after comparing this fungus with some strains of this genus $\left.{ }^{3)},{ }^{4)}, 5\right)$.**

Although dark pigmentation is known up to now as one of the characteristics of Pullularia, the new isolate does not produce dark pigment on most media. Also, the appearance of the giant colony of this isolate is peculiar, compared with those of other species of Pullularia.

Comparative studies of pigmentation and growth characteristics of all the recognized species of Pullularia, including the new isolate, were therefore made under various conditions.

Wynne in $1956^{6}$ ) proposed a revision of the genus Pullulria based almost entirely on biochemical and physiological considerations rather than on morphology. An attempt was therefore made by the author to classify the new isolate according to this new scheme.

Among the species of Pullularia studied, the new isolate resembles the genus Candid $\boldsymbol{a}^{7}$ ) most closely. It may thus be given attention by some mycologists because it might fill a phylogenetic gap between the group of "Yeasts" and some black "Fungi Imperfecti ".

\section{Materials and Methods}

Materials: 1) the fungus in question isolated from the rutin solution, perhaps air-borne, the Univ. of Tokyo, Japan, 2) a culture of so-labelled Pullularia pullulans

\footnotetext{
* Biological Laboratory, Minami-Bunko, Hiroshima University, Hiroshima, Japan. 広島大学, 皆夹分校, 生物学教室

** According to Mr. I. Noguchi, Dr. S. Hattori's co-worker, the property of degrading rutin as seen in the new variety is also observed in the Nagao strain of Pullularia and Pullularia fermentans var. fermentans but not in Saccharomyces cerevisiae and very poorly in Aspergillus niger. The property of degrading rutin may therefore be a distinguishing characteristic of the genus Pullularia.
} 
from the Nagao Institute, Japan,* 3) a culture of Pullularia werneckii from Prof. Dr. K. Minoura, Osaka Univ., Japan and 4) a culture of Pullularia fermentans var. fermentans from Dr. Wynne, Texas Univ., Texas (U.S. A.).

Culture media used: malt extract, malt extract agar, Sabouraud dextrose agar (Difco), dextrose-peptone agar,** corn-meal agar (Difco), nutrient agar (Difco), Littman oxgall agar (Difco), microassay culture agar (Difco), Czapek dextrose agar, ammonium sulfate medium, ${ }^{* * *}$ potassium nitrate medium.****

Cultures were made on malt extract, nutrient broth (Difco), in test tubes, Sabouraud dextrose agar (Difco), dextrose-peptone agar, corn-meal agar (Difco), nutrient agar (Difco), Littman oxgall agar (Difco), microassay culture agar (Difco), Czapek dextrose agar, ammonium sulfate medium and potassium medium on both slant and plate, respectively. These cultures were incubated aerobically at $25^{\circ}$ and observed on alternate days for the presence of pigmentation and growth. Final readings were made at the end of two weeks. Maximum temperature for the growth of fungus was tested on malt extract and malt extract agar at $37^{\circ}$, after two weeks. Method for testing the production of acid from carbohydrates was that of Wynne, except that a Horiba $\mathrm{pH}$ meter was used instead of a Beckman Model G pH meter.

\section{Experimental Results}

1. Classification of the new isolate in the genus Pullularia:

Classification was based both on morphological and on physiological considerations and comparison with known strains of the genus Pullularia (Fig. 1). Blastospores $4-7 \times 8-13 \mu$, chlamydospores $7 \times 10-13 \mu$, arthrospores $6 \times 13-15 \mu$, cladosporium forms $7 \times 13 \mu$. On Sabouraud dextrose agar, 14 days, at $25^{\circ}$, flat, light colored colony with white surface mycelium, finely fuzzy margin. On malt extract agar, at $25^{\circ}$, at first light pinkish-lilac colored, $\left.{ }^{8}\right)$ later dark pigmentation. No dark pigment produced on almost all media such as nutrient agar, corn-meal agar, Littman oxgall agar, microassay agar, Czapek dextrose agar, ammonium sulfate medium and potassium medium. Light colored rings of pellicle in broths such as nutriert, phenol red base broth containing various sugars. No aerial mycelium observed. No growth at $37^{\circ}$. Ferments dextrose, mannose, sucrose, raffinose and xylose.

\section{Pigmentation:}

Observations on the pigmentation of some strains of Pullularia including the new

* The author is indebted to the Nagao Institute for supplying the culture.

** The components of this medium were the same as that of Sabouraud dextrose agar (Difco) except that the peptone was purchased in Japan from the Kyokuto-Seiyaku Co.: Bacto-dextrose-10 g., Peptone (Kyokuto-Seiyaku) - 40 g.,Bacto agar-15 g., per 1 liter dist. water.

*** Dextrose--30 g., $\left(\mathrm{NH}_{4}\right)_{2} \mathrm{SO}_{4}-5$ g., $\mathrm{KH}_{2} \mathrm{PO}_{4}-1$ g., $\mathrm{MgSO}_{4} \cdot 7 \mathrm{H}_{2} \mathrm{O}-0.5$ g., Bacto-agar-15 g., per 1 liter of dist. water.

**** Dextrose $-30 \mathrm{~g}$., $\mathrm{KNO}_{3}-30$ g., $\mathrm{KH}_{2} \mathrm{PO}_{1}-1$ g., $\mathrm{MgSO}_{4} \cdot 7 \mathrm{H}_{2} \mathrm{O}-0.5$ g., Bacto-agar-15 g., per 1 liter of dist. water. 

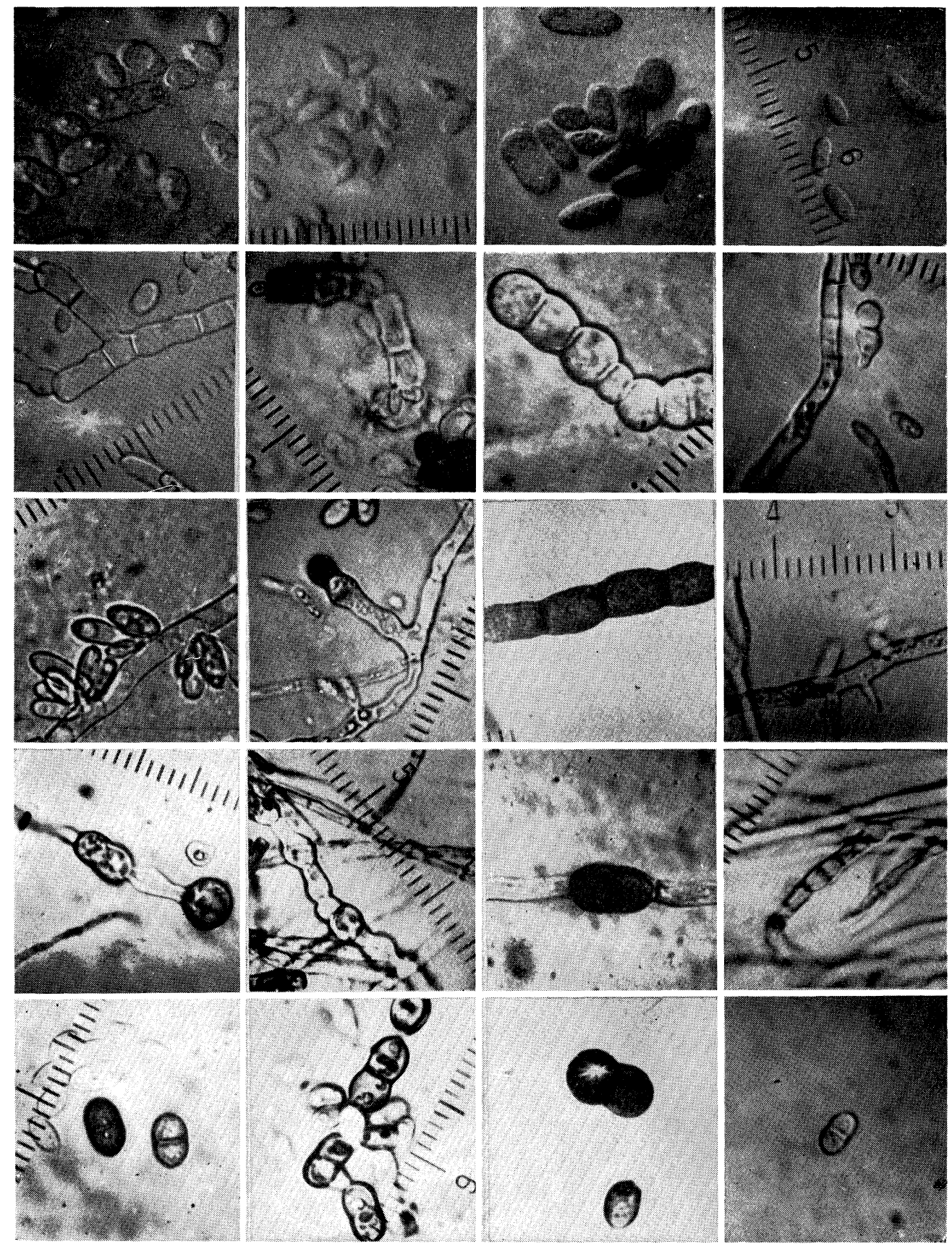

Fig. 1 Microscopic morphology of the Pullularia.

Vertical column

1 st row, the new variety.

2 nd row, $P$. fermentans var. fermentans.

3 rd row, Nagao. strain, so-labelled Pullularia pullulans.

4 th row, P. uerneckii.

Horizontal column

1 st, blastospores, on Sabouraud dextrose agar, 3 days, at $25^{\circ}$.

2 nd, and 3rd., arthrospores and mycelial hyphae.

4 th, chlamydospores

5 th, cladosporium forms.

All are the same enlargement; one scale unit, $2.5 \mu$. 

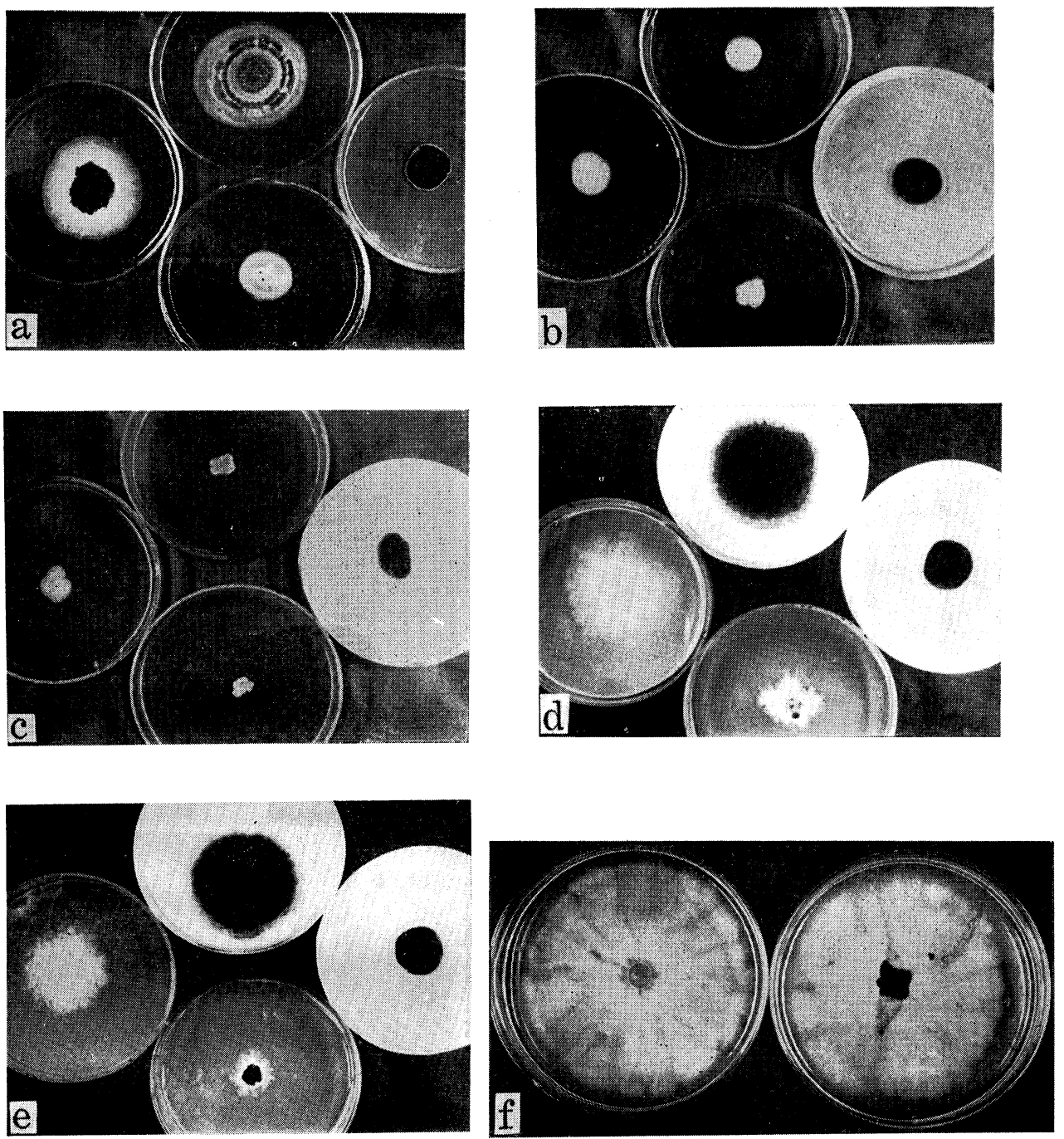

Fig. 2 Giant colonies of some strains of Pullularia on various media. $\mathrm{a}, \mathrm{b}$, and $\mathrm{c}$, malt extract agar with $\mathrm{NaCl} ; \mathrm{a}, 5 \%$; b, $10 \%$,

c, $12.5 \%$, respectively.

d, Czapek dextrose agar; e, Potassium nitrate medium;

$\mathrm{f}$, Sabouraud dextrose agar with vitamin $\mathrm{B}_{12}, 100 \mu \mu \mathrm{g}$. per $1 \mathrm{ml}$. added.

a-e, upper, Nagao strain;

left, new variety;

right, $P$. werneckii;

lower, $P$. fermen'ans var. fermentans.

$\mathrm{f}$, right, $P$. fermentans var. fermentans:

left, new variety. 
Table 1. Pigmentation of Pullularia on various media.*

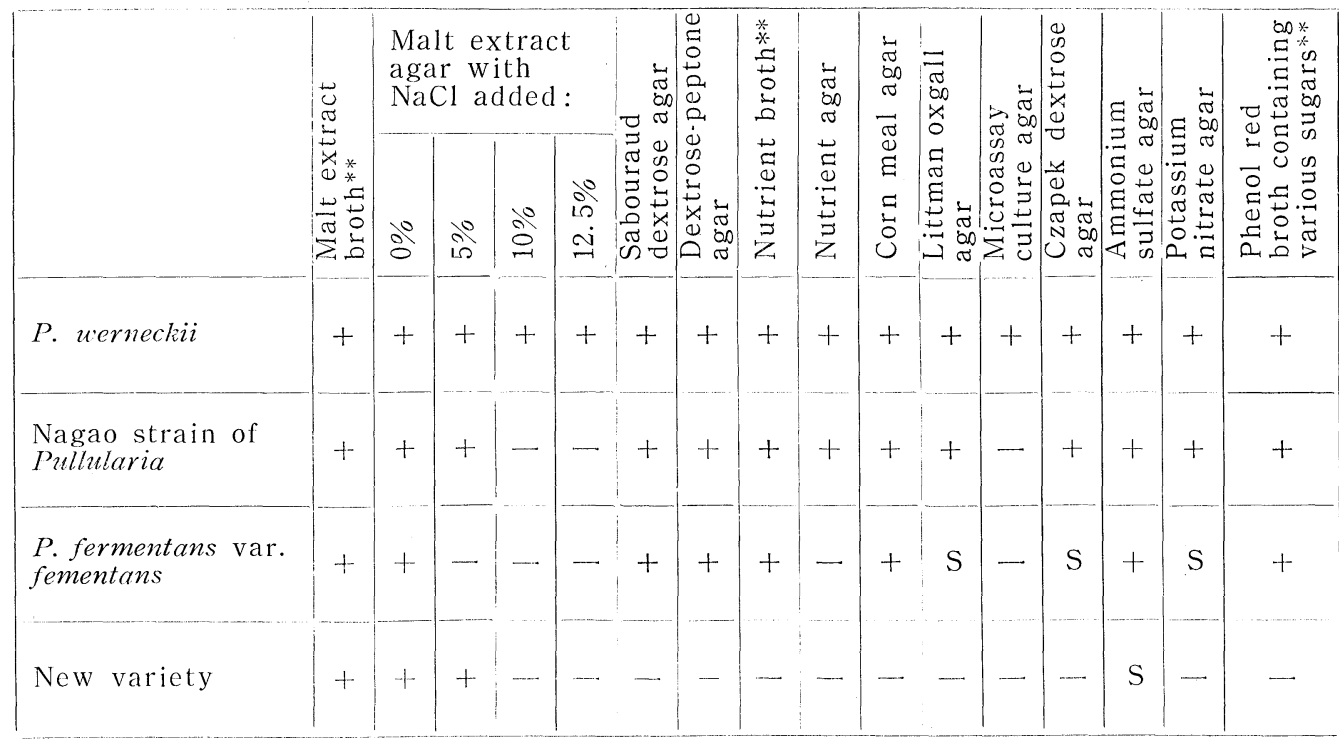

* Readings were made on the slant cultures at the end of two weeks at $25^{\circ}$.

** Pellicle pigmentation.

+ dark pigmentation.

S slightly dark pigmentaion.

- no dark pigmentation.

variety, are shown in Table 1 and partly Fig. 2. It was found that distinctly dark pigmentation occurred on the slant Czapek agar culture of $P$. fermentans var. fermentans when some amount of vitamin $\mathrm{B}_{12}$ was added (20-100 $\mu$ g.) (Fig.3).

3. Giant colony:

A giant colony of the new variety was different from those of other species of Pullularia (Fig. 2-d, e, and Fig. 4). In the case of P. werneckii, mycelial phase is so predominant that it is called "mold growth"6). On the contrary, the new variety produced more blastospores than mycelial cells. Besides, most of the blastospores did not become mycelial cells which is usual in " mold growth" type strain, but new blastospores sprouted again and again. Besides, it was often seen that a blastospore detatched from the mother cell as if it sprang out (Fig. 5).

4. The rate of growth in Pullularia:

The Nagao strain, the new variety, $P$. fermentans var. fermentans and $P$. werneckii were in order not only in rapid growth but also in size of giant colonies up to three weeks. This was the case when these fungi were compared with each other grown in parallel on plate cultures of such media as malt extract agar, dextrose-peptone agar, nutrient agar, corn-meal agar, microassay culture agar, Czapek agar, ammonium sulfate medium, potassium nitrate medium (Fig. 2-d, e, and Fig. 4).

\footnotetext{
* Rubramin, E.R. Squibb L \& Donds, New York, Division of Olin Mathieson Chemical.
} 


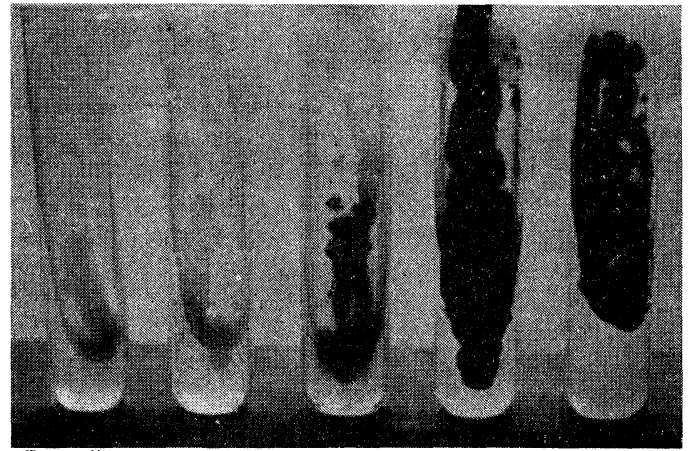

Fig. 3
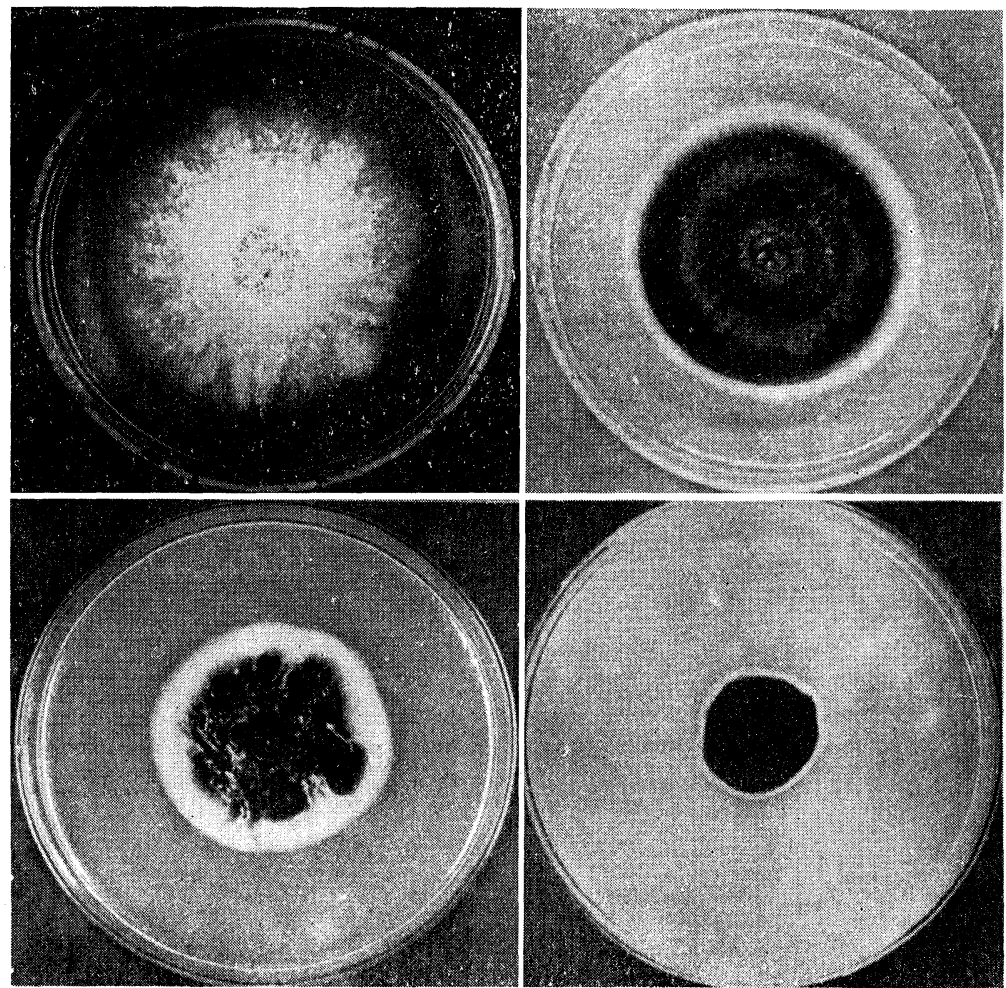

Fig. 4

Fig. 3 Five tube nutritional test of $P$. fermentans var. fermentans left to right,

(1)-(3), Czapek agar:

(1), blank,

(2), with vitamin $B_{12}, 20 \mu \mu$ g.per $1 \mathrm{ml}$. added.

(3), with vitamin $B_{i 2}, 100 \mu \mu \mathrm{g}$. per $1 \mathrm{ml}$. added.

(4)-(5), Sabouraud dextrose agar:

(4), blank,

(5), with vitamin $\mathrm{B}_{\mathrm{i} 2}, 100 \mu \mu \mathrm{g}$ per $1 \mathrm{ml}$. added.

Fig. 4 Giant colonies of some strains of Pullularia, in which emphases were placed on their appearances as well as their pigmentation, on Sabouraud dextrose agar at $25^{\circ}$, two weeks, with exception of one week of Nagao strain. Upper left, new variety: upper right, Nagao strain; lower left, P. fermentans var. fermentans; lower right. P. werneckii.

Fig. 5 Showing the blastospores sprouting from a short mycelial cell of the new variety of Pullularia.

Hanging drop culture of malt extract, $25^{\circ}$; upper, original; middle. after 30 minutes; lower, after 40 minutes. 
When $100 \mu \mu \mathrm{g}$. per $\mathrm{ml}$. of vitamin $\mathrm{B}_{12}$ was added to the Sabouraud dextrose agar plate cultures of the new variety and $P$. fementans var. fermentans the growth of the latter fungus was promoted and the appearances of the two fungi bore a resemblance to each other, with the exception of the pigmentation at the central portion (Fig. 2-f).

5. Salt tolerance:

As seen in Fig. 2, on malt extract agar added with $12.5 \% \mathrm{NaCl}$ the growth of $P$. fermentans var. fermentans and the Nagao strain were extremely inhibited, but the new variety as well as $P$. werneckii was not affected so much.

\section{Discussion}

\section{Classification of the new isolate:}

The new isolate seems to be most closely related to Pullularia fernentans var. fermentans though the characters of light hyphae and the peculiarity of the giant colony of this fungus would seem to eliminate other varieties of $P$. fermentans described up to now as the variety for this new isolate.

The name of Pullularia fermentans var. candida is proposed, since it resembles the fungi in the genus Candida as stated often in this paper.

Pullularia fermentans Wynne et Gott. var. candida Yoneyama var. nov.

Blastosporae $4-7 \times 8-13 \mu$, chlamydosporae $7 \times 10-13 \mu$, arthrosporae $6 \times 13-15 \mu$, cladosporium format $7-13 \mu$. Coloniae in agarico dextroso-peptone planae, pallide roseolilacinae, mucosae, area centrali elevata irregulariter tuberculata, margine subtiliter fimbriatae. Pigmentum produtum and centrum in agarico maltoso et dextroso Sabouraudii: Nullum pigmentum in agaro farinae frumanti, in agaro Littmani, in agaro nutriente, inagarum Czapekii. Non crescit cum $37^{\circ}$. Glucosum, mannosum, maltosum, sucrosum, raffinosum et xylosum fermentat.

Isolata in culturis ex solutione rutinorm in Tokiensi, Japonia.

\section{Pigmentation:}

The following schema would help to explain the occurrence of pigment in species belonging to Pullularia:<smiles>[Y][14C](O)[14C](O)O</smiles>

$O$ represents a genic factor which would cause the pigmentation in all species of Pullularia, leading to $\mathrm{Q}$ which represents pigmentation. $\mathrm{P}$ is something which would play a role between $\mathrm{O}$ and $\mathrm{Q}$. $\mathrm{X}$ is a substance which may be responsible for processing of the course $\mathrm{O} \rightarrow \mathrm{P}$, and $\mathrm{Y}$, another substance for the course $\mathrm{P} \rightarrow \mathrm{Q}$. It seems to be a characteristic of the pigmentation in Pullularia that the course $\mathrm{O} \rightarrow \mathrm{P} \rightarrow \mathrm{Q}$ is followed.

Dark coloring strains such as $P$. pullulans, $P$. werneckii, and the Nagao strain seem to be capable of completing this course, that is, they have strong genic factors and 
are able to produce both $\mathrm{X}$ and $\mathrm{Y}$ on most media; whereas the new variety seems not to complete this course, that is to say, it has a certain genic defect or failure as regards the course, so that it does not produce $X, Y$, or both of them $\left.{ }^{9},{ }^{10)},{ }^{11}\right), 12$. That the pigmentation of the new variety does occur on malt media is not easy to explain, but $\mathrm{X}$ or $\mathrm{Y}$, or a substance or substances which might induce occurrence of $\mathrm{X}$ or $\mathrm{Y}$, in the fungus may be present in malt extract. P. fermentans var. fermentans seems to have an intermediate position between the two type

3. Giant colony:

A giant colony is, as Bornside ${ }^{13)}$ pointed out, regarded as a group of cells arranged as a result of fungal development and environmental conditions. So the difference between two giant colonies of the two species of fungi on the same solid media may possibly due to two factors: 1) the way, in which the fungus tends to produce either yeast-like cells or mycelial cells, 2) mode of vegetative reproduction, i. e budding or mycelial elongation plus branching.

Regarding the conversion of the mycelial cells to yeast-like cells, there appeared several reports ${ }^{14},{ }^{15)},{ }^{16)},{ }^{17)},{ }^{18}$, which ascribed the conversion to the effect of cultural conditions. However, yeast-like cells which appear predominantly and the peculiar mode of their sprouting as seen in the culture of the new isolate may be used as taxonomic criteria ${ }^{19}$, when compared with other species of Pullularia under a certain condition.

4. The growth of the species in Pullularia:

The fact that the growth of $P$. fermentans var. fermentans could be promoted on Sabouraud dextrose agar by adding a little quantity of vitamin $B_{12}$ suggests that a simple chemical substance may be of some relation to the growth of the fungus as is the case with the production of dark color. It is therefore apparent that there exists an intimate affinity between P. fermentans var. fermentans and the new isolate.

5. Salt tolerance (Tolerance in hypertonic medium):

This property should be sufficient in making a distinction between the new variety and $P$. fermentans var. fermentans or the Nagao strain; it is likely to assume its natural habitat is different from those of other species. However, it is regrettable to say that the natural habitat is unknown to us up to now.

The following schema may be finally drawn:

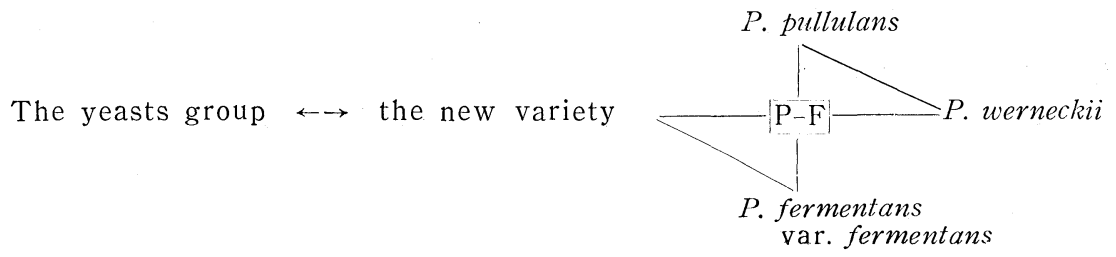


Moving from the right (dark fungi) to the left (the yeast group), there is decrease in pigmentation and rate of the mycelial phase. Fermentation ability is present in P. fermentans and the new variety and P-F (center of the schema, which is not an actual species but an imaginative one). Many examples which corresponded to P-F were discovered by Wynne and the Nagao strain seemed to be an example of this type.

\section{Summary}

1. A taxonomic study was made of an organism isolated from rutin solution and to which the name of Pullularia fermentans var. candida was given by the lack of dark pigment of hyphae on most media and by the peculiar appearance of a giant colony from abundance of blastospores and the mode of their sprouting.

2. Comparison of dark pigmentation and giant colonies of the species of Pullularia was made, respectively; the lack of dark pigmentation and the peculiarity of a giant colony of the new variety were considered to be worthy of using as taxonomic criteria.

3. The position of the new variety which seems to be an intermediate form between the genus Pullularia and the genus Candida (Yeast) was discussed.

4. A substance which might be responsible for possible pigmentation or growth of the Pullularia was presumed.

\section{Acknowledgments}

The author's thanks are due to Dr. S. Hattori and Mr. I. Noguchi, University of Tokyo, for their suitable advice and encouragcment throughout this study; to Dr. E. S. Wynne, University of Texas, Houston, Texas, and Dr. K. Minoura, Osaka University, for cultures of P. fermentans and P. werneckii, respectively ; to Drs. K. Saito, H. Naganishi, and Y. Kobayasi for their valuable advice on the taxonomic classification of this study; and to the Bacteriology Staff of ABCC, Hiroshima, especially Mr. H. M. Yamashiroya, for their technical assistance and their advice.

\section{Referernces}

1) Hattori, S. and Noguchi, I., Bot. Mag. Tokyo 71: 43 (1958). 2) Mark, E. M., Food Technology $11: 541$ (1957). 3) Barnett, H. L., Illustrated Genera of Imperfect Fungi (1955). 4) Conant, N. F., Journ. Bact. $41: 563$ (1941). 5) Dodge, C. W., Medical Mycology 672 (1935). 6) Wynne, E.S. and Gott, C. L., Journ. General Microbiology $14: 512$ (1956). 7) Lodder, J. and Kreger-van Rij, N. J. W., The Yeasts (1952). 8) Ridgway, R., Color standards and nomenclature (1912). 9) Kobuyama, Y., Nihei, J., Tanaka, S., and Mori, H., Journ. Soc. Brewing, Japan $48: 278$ (1953). 10) —_, and Ueno, K., Journ. Soc. Brewing, Japan 48: 357 (1953). 11) Takagi, Y. and Sakaguchi, K., Journ. General and Applied Microbiology 3: 125 (1957a). 12) - - - ibid. 4:269 (1957b). 13) Bornside, G. H. and Richardson R. L., Journ. Bact. $75: 89$ (1958). 14) Campbell, C. C., Journ Bact. $54: 263$ (1947). 15) — Manual of Clinical Mycology (1944). 16) Pine, L., Journ. Bact. $74: 239$ (1957). 17) and Peacock, C. L., Journ. Bact. 75 : 167 (1958), 18) Salvin, S. B., Journ. Bact. 54 : 655 (1947). 19) Durie, E. B. and Frey, D., Mycologia $49: 401$ (1957). 
東大の服部教授の研究室で，ルチンを分解する菌が分離されたので，その同定を行なった。本菌は酵母に 非常によく似ているようだったが, 培養条件により Pullularia の特徵の片鱗を示したので, 長尾研究所か らの Pullularia pullulans と比較してみて, Pullularia に属させるべきものとわかった。

Pullularia は促来 P. pullulans と P. werneckii の 2 種だけ知られていたが, Wynne (1956) は ホジキ ン氏病患者の病坚から Pullularia を分離し，それがある炭水化物から酸を生成するので Pullularia fermentans という新種をもうけて Pullularia 属の定義を修正するよう提唱した。その修正の基礎はP Pullularia の分類のを規準として炭水化物からの酸形成能を採用するてとにある。東京からの本菌は, その形態と Wynne の提唱による分類規準とからみて P. fermentans var. fermentans にもっとも近縁であった。し かしたいていの培地上で Pulluaria の特徵である暗色色素を形成しないとと, 巨大コロニ一の樣䧋が特異 であるととから新変種とし，Pullularia fermentans var. candida とした。なお本菌は高張培地にもかな りよく耐えるが，それは比較に用いた P. fermentans var. fermentans や長尾研究所からの菌 so-labelled P. pullulans とも異なるので, 乙の新変種の天然のすみか㳉, 従来しられている Pullularia のすみかとは 異なつたものと思われる。

この研究では Pullularia の四つの菌粎について, 暗色色素の形成とコロニ一の様相が種々の条下件で 比較されたが, Pullularia の暗色色素形成と生長の速度とが，ある場合には，簡単な化学物質によって支 配されるととがわかった。それで Pullularia のある菌怢は microbioassay の研究材料としてもよいので はないかと思われる。 